\title{
EXPLORING THE RELATIONSHIP BETWEEN ENTREPRENEURSHIP AND UNEMPLOYMENT RATE IN INDUSTRIAL SECTOR OF AZARBAYJAN-E-SHARGI
}

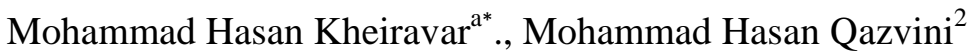 \\ a. Ph.D Student, Allameh Tabatabai University \\ b. Industrial management institute, Management and economic consultation center
}

\begin{abstract}
Since employment is one of the core requirements of society, and unemployment is the origin of many economic, social, and cultural anomalies, the necessity of investigating the current status of unemployment in the province, aswell as, the heavy responsibility of the central government and local officials to generate employment and alleviate unemployment comes into prominence. Accordingly, entrepreneurship as a key tool for creating jobs, and reducing unemployment rate takes on increasing importance among the country's experts and policy makers. A great deal of uncertainty surrounding the kind of relationship between entrepreneurship and unemployment exists in developing countries. Some experts state that there is a positive relationship between these two economic variables, i.e., as unemployment rate rises, after a few-year interval, entrepreneurship rate also augments. On the other hand, some experts indicate an inverse relationship between entrepreneurship and employment, i.e., promotion of entrepreneurial activities brings down the rate of unemployment.

The current study attempted to investigate the relationship between entrepreneurship-with the concept of creating a new business- in the industry of Azarbayjan-e-Shargi and unemployment rate in this province. Vector auto-regression (VAR) econometrics was employed in examining this relationship. The findings indicated that, in industrial sector of Azarbayjan-e-Shargi, an inverse relationship existed between entrepreneurship and unemployment rate.
\end{abstract}

Keywords: unemployment, entrepreneurship, vector auto-regression

* Corresponding Author: ebrahimpourh@yahoo.com 


\section{Introduction}

Many economists believe that, entrepreneurship, as the engine of economy, performs various roles in society, and regard it as the basis for all human evolutions and achievements. Exploiting the generating power that they find in themselves as a means of creative problem solving, entrepreneurs, are able to, as wisely, delicately, and rapidly as possible, change environmental threats and restrictions into opportunities, and in severe conditions, such as hyper unemployment, currency shortage, inflation, war, etc., find new opportunities and take advantage of them for the benefit of themselves and society. The majority of entrepreneurs enter the market while they introduce new products and new production techniques (Acs \& Audretsch, 2003); by means of offering a wide range of products and diversified services, they can improve our knowledge about practical and technical feasibility of producing many products, final consumers' taste, and how to supply required sources, furthermore, they can enhance efficiency as the result of increasing the competition (Geroski, 1989; Nickell, 1996; Nickell et al, 1997). Moreover, entrepreneurs devote more hours, with higher efficiency, to working, because their income has a significant link with their work rate, therefore, they exert a positive impact on economic growth (Carree \& Thurik, 2003). In short, entrepreneurship affects overall efficiency of economy (Van et al, 2005).

However, the issue that entrepreneurship development is the result of which macroeconomic variable, and to what extent entrepreneurs can be effective in decreasing societies' unemployment rate have been the subject of economists' and policy makers' debates over the last century, and many uncertainties have surrounded the kind of relationship between entrepreneurial activities and unemployment. Considering that, a rise in unemployment level causes the entrepreneurial opportunity cost to reduce markedly, and encourages more people to be self-employed and create new businesses, some economists note that there is a positive relationship between these two variables, and a rise in unemployment leads to entrepreneurial growth. On the other hand, some researchers find entrepreneurship activities as job-creating, and assume an inverse relationship between the variables in question. They argue that, since entrepreneurship and starting new businesses are inseparable, and every new firm creates employment at least for its own founder, a rise in entrepreneurship would reduce the level of unemployment.

The current paper, aimed at exploring the relationship between entrepreneurship in industrial sector of Azarbayjan-e-Shargi and unemployment rate in this province, has been compiled in five chapters: Following the introduction section, theories, and results of the most important empirical studies conducted in this field are presented in the second chapter. Methodology, statistical data, and descriptive statistics are presented in chapter three. Chapter four involves analyzing the empirical findings, and in the last chapter, conclusions are stated and some recommendations are offered.

\section{Literature Review}

A problem lying in the high rate of unemployment and its unfortunate consequences on societies, policy makers have obliged all countries to search for theoretical bases about appropriate means for reducing unemployment rate. As a consequence, gaining information about the role of entrepreneurship policies in alleviating unemployment has become policy makers' perturbation.

Many experts consider innovators and entrepreneurs as the engine of economic achievements in every society, and believe that small and medium-sized firms-founded as the result of entrepreneurial activities- depending on their coordinate and characteristics, can perform effectively in boosting employment. Furthermore, statistics of different countries proves that a large part of permanent jobs is 
created by small entrepreneurial firms. In this regard, in developed countries, entrepreneurship is regarded as the source of economic growth and employment, and their public policies have developed a tendency towards full development of entrepreneurship in order to generate employment and reach a steady economic growth. Nevertheless, the relationship between entrepreneurship and unemployment has become a source of ambiguity for the experts.

Unquestionably, small firms and new businesses are created in certain times and places, influenced by social, economic, and other sorts of supports, which are favourable to entrepreneurs. Since creating ideal environments by central governments and local policy makers to establish small and steady firms and develop entrepreneurship, require high cost and extra attention, certain questions as to, whether a statistically significant relationship exists between entrepreneurship and unemployment rate, what is the features of such relationship (if exists), and how and to what extent definition and creation of entrepreneurial networks in various specialized fields, as a necessity to develop entrepreneurship, can be effective in reducing unemployment, arise in minds of many scientists and policy makers.

Surveys conducted to answer the above-mentioned questions have reported inconclusive and sometimes contradictory results. In fact, existing empirical evidence derived from studies undertaken in the field of entrepreneurship and unemployment is indicative of similar uncertainties. Some researches indicate a positive link between unemployment and entrepreneurship, while others show an inverse relationship between these two economic variables (Thurik, 1999).

Additionally, referring to Gibrat's Law, some policy makers do not find sufficient justification for entrepreneurship development policies, and an increase in self-employment and the number of small industries. Gibrat's Law considers firm growth independent from its size. This law states that transferring employment from large firms to small ones will not have any effect on overall employment rate. Since the expected growth rates of both firm types are distinct from Gibrat's standpoint, transference of economic policies' focus from large firms to small ones, and corresponding change of structures, would not exert any effect on overall unemployment rate.

Nonetheless, there are powerful evidences which contradict with Gibrat's law concerning the firm size. For example, some comprehensive studies (e.g., Dunne, Roberts, Samuelson, \& Evans, 1987a, 1987b; 1988, 1989; Hall, 1987; Sutton, 1997) indicate that small firms experience more growth rate compared to large ones. These findings, regardless of differences among countries, the time of the studies, the industries, and the adopted methodologies, have been almost supported by following researches.

Furthermore, many empirical evidences emphasize that new and small firms perform better than older and larger ones in terms of job creation. In addition, other researches demonstrate that as the firm gets older, its size and age are eliminated (Hart \& Qulton, 1999).

Although, the findings revealing that small firms and industries experience a faster growth compared to large firms and industries, have been obtained by studying the microeconomic data, they can demonstrate small firms' positive and remarkable effect on economic efficiency of the countries under study. In these studies, the rate of self-employment and entrepreneurship are considered as criteria for the active participation of industries and small firms in the economy. Nevertheless, the findings, suggesting that higher rate of self-employment and entrepreneurship can automatically lead to economic efficiency improvement, are not obvious and definite in studies conducted in all countries, and entrepreneurship may be inefficient in some countries (e.g., .Carree, Van Stel, Thurik, Wennekers, 2002, 2007). For instance, Carre et al., (2002, 2007) state that, countries with relatively low rate of entrepreneurship, make use of entrepreneurship development for boosting gross domestic production, on the contrary, those with high rate of entrepreneurship do not behave in the same way. Moreover, Blanchflower (2000), focusing on 
OECD countries, arrives at this conclusion that there is not any positive link between self-employment rate and gross domestic production growth.

A large number of experts, having studied their selected society, claim that a positive and statistically significant relationship exists between unemployment and entrepreneurship, and believe that an increase in unemployment rate would bring about a rise in entrepreneurship. Such discussion has its root in the first research into the relationship between unemployment and entrepreneurship in 1943 (Oxenfeldt) (Parker, 2004; Grilo \&Thurik, 2005; Griloand \& Irigoyen, 2006).

This group, defining the term "refugee effect", note that the high rate of unemployment and unfavorable job prospects, force individuals to attempt to engage in self-employment; they believe that deciding to become an entrepreneur is a reaction against becoming unemployed. As a consequence, the high rate of unemployment encourages more people to become entrepreneurs. For example, Evans and Leighton (1990) indicate a positive link between unemployment and creating more new firms.

A bulk of studies in this field (e.g., Evans and Leighton,1989,1990; Hamilton, 1989; Highfield, Smiley, 1987; Reynolds, Miller , Maki, 1995; Reynolds, Storey, Westhead, 1994; Yamawaki, 1990), reinforcing this view, introduce hyper unemployment as a catalyst for entrepreneurial activity.

On the other hand, critics of this view, remarking that founding and managing a new firm and business require a remarkable human capital and entrepreneurial talent, offer their lower human capital in comparison with employed people as the reason for unemployment among people, and conclude that an increase in unemployment rate and hyper unemployment would lead to a fall in self-employment and entrepreneurship (Hurst \& Lusardi, 2004; Johansson, 2000). Additionally, some studies' (e.g., Audretsch \& Fritsch, 1994; Garofoli, 1994) results which are suggestive of unemployment's negative effect on creating new firms, are in line with the critics' opinion.

Furthermore, another group of researchers, regarding an inverse relationship between entrepreneurship and unemployment rate, believe that entrepreneurship and entrepreneurial spirit have a dramatic effect on decreasing unemployment, and refer to it as an entrepreneurial effect. They argue that, every new firm or new business, primarily, employs workforce, which leads to a fall in unemployment (Lin, Manser \& Picot, 1998; Pfeiffer\& Reize, 2000). Moreover, Thurik and Audretsch (2000), indicating that an increase in the number of industry owners, which results in new firm formation, reduces unemployment rate, corroborate the effectiveness of entrepreneurship.

On the whole, one group of researchers hold the view that there is a positive relationship between entrepreneurship and unemployment, and the other group have the view that a negative relationship exists between the variables. Furthermore, a small number of theorists, (e.g., Caree, 2002) claim that no statistically significant relationship exists between entrepreneurship, i.e., the number of new firms, and unemployment. Additionally, Geroski (1995) believes that the proportion of new firms is so much lower than that of total employment, and the contribution of entrepreneurial activities to a fall in unemployment is very limited.

Consequently, economic experts confront many problems about recognizing the kind of relationship between entrepreneurship and unemployment, and as mentioned before, uncovering the nature of this relationship is important because it can help economic policy makers in making crucial decisions.

To summarize, theoretical reasons as well as empirical evidences indicate the existence of a two-way relationship between entrepreneurship and unemployment rate. That is, unemployment brings about a rise in entrepreneurship, which leads to a fall in unemployment. With regard to the point that, policies are formulated based on hypotheses with no ambiguity, revealing the relationship between entrepreneurship and unemployment appears to be vital. 
The present paper has been designed to make attempt to resolve and clarify the dubiety surrounding the relationship between entrepreneurship and unemployment in industry (establishing new industrial firms), in Azarbayjan-e-Shargi province.

\section{Methodology, Research Model, and Statistical Database}

Descriptive statistics associated with the number of licenses issued each year to create and launch new manufacturing businesses-entrepreneurship-as well as the province's unemployment rate over the last ten years are studied. This information has been derived from statistical annals of Azarbayjan-e-Shargi in different years, as well as, statistics of industrial workshops of Statistical Center of Iran.

\subsection{Descriptive statistics}

The number of licenses issued each year for industries are applied as an index of entrepreneurship in the whole industrial structure.

According to the information gained, the number of licenses issued each year for industries are displayed in Table 1:

Table1. The number of licenses issued each year

\begin{tabular}{|c|c|c|c|c|c|c|c|c|c|c|}
\hline Year & 1997 & 1998 & 1999 & 2000 & 2001 & 2002 & 2003 & 2004 & 2005 & 2006 \\
\hline Number & 359 & 332 & 491 & 464 & 598 & 669 & 614 & 481 & 427 & 472 \\
\hline
\end{tabular}

Source: Statistical annals of Azarbayjan-e-Shargi province-different years- Statistics Center of Iran

Figure 1 displays the process of the number of licenses issued:

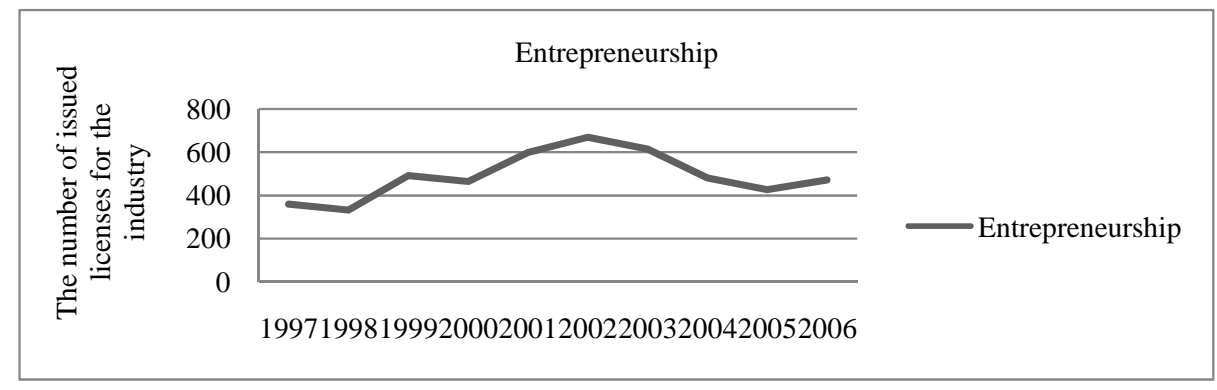

Figure1. The number of licenses issued in the province' industry from 1997 to 2006

This process shows that, from 1997 to 2002, the number of licenses issued in the industry of Azarbayjane-Shargi has grown, however, from 2002 to 2005, it has declined. The drop in the number of licenses issued during that period may be explained by a probable rise in the risk of investment in the industry of the province and country in those years. Foreign competitors' cheap product offerings, a lack of adequate public and government support for new businesses, inefficient labor rules, tax, financial security, etc. cause more industries to face bankruptcy and closure, and finally, it can justify the transfer of private sector's potential and real industrial capitals (financial, human, etc.) to speculation and other sectors of economy. 


\subsection{Inferential statistics related to unemployment rate}

Employment and unemployment are of fundamental issues of every county's economy, and a rise in employment and a fall in unemployment are considered as one of the criteria for societies' development. As a consequence, making efforts to bring down unemployment is one of the major concerns in development programs. Furthermore, information about workforce structure and estimation of workforce indices are regarded as a basis for evaluation and analysis of macroeconomic policies. The Research Center of Islamic Consultative Assembly has explored strategies towards regional employment in the country, according to the information office of this center, a report prepared in the same field by the bureau of Economic Research of this center, this report, addressing the youth unemployment rate in urban and rural areas, state that: investigation of unemployment rate in the country's various provinces between the years 2001 and 2003 suggests that Sistan Baluchestan face the highest rate of unemployment and Azarbayjan-e-Shargi face the lowest rate of unemployment.

The information about the rate of unemployment in Azarbayjan-e-Shargi, separating males from females, based on the latest statistics, is displayed in Table 3:

The province's unemployment rate without sex segregation from 1997 to 2006 is shown in table 2:

Table 2: Unemployment rate of the province (1997-2006) in percentage terms

\begin{tabular}{|c|c|c|c|c|c|c|c|c|c|c|}
\hline Year & 1997 & 1998 & 1999 & 2000 & 2001 & 2002 & 2003 & 2004 & 2005 & 2006 \\
\hline Unemployment Rate & 6.11 & 6.02 & 5.93 & 5.86 & 5.79 & 5.72 & 5.66 & 5.61 & 5.61 & 5.60 \\
\hline
\end{tabular}


Kheiravar and Qazvini., International Journal of Organizational Leadership, Vol. 1 No. 2 (2012)

Table 3: The estimation of unemployment rate in the province Azarbayjan-e-Shargi with sex segregation from 1997 to 2006

\begin{tabular}{|c|c|c|c|c|c|c|}
\hline Sex & Year & $\begin{array}{c}\text { Population } \\
\text { (ten years and } \\
\text { above) }\end{array}$ & $\begin{array}{c}\text { Active } \\
\text { Population }\end{array}$ & $\begin{array}{l}\text { Employed } \\
\text { Population }\end{array}$ & $\begin{array}{l}\text { Unemployed } \\
\text { Population }\end{array}$ & $\begin{array}{c}\text { Unemployment } \\
\text { Rate }\end{array}$ \\
\hline \multirow{10}{*}{ Male } & 1997 & 1329354 & 865158 & 813875 & 51283 & $5 / 93$ \\
\hline & 1998 & 1357264 & 886994 & 833254 & 53741 & $6 / 06$ \\
\hline & 1999 & 1385174 & 908831 & 852632 & 56198 & $6 / 18$ \\
\hline & 2000 & 1413085 & 930667 & 872011 & 58656 & $6 / 30$ \\
\hline & 2001 & 1440995 & 952504 & 891390 & 61114 & $6 / 42$ \\
\hline & 2002 & 1468905 & 974340 & 910769 & 63572 & $6 / 52$ \\
\hline & 2003 & 1496815 & 996177 & 930147 & 66029 & $6 / 63$ \\
\hline & 2004 & 1524725 & 1018013 & 949526 & 68487 & $6 / 73$ \\
\hline & 2005 & 1540534 & 1044234 & 973558 & 70676 & $6 / 77$ \\
\hline & 2006 & 1556342 & 1070456 & 997590 & 72865 & $6 / 81$ \\
\hline \multirow{10}{*}{ Female } & 1997 & 1309148 & 157242 & 146026 & 11216 & 7/13 \\
\hline & 1998 & 1335145 & 182365 & 171702 & 10662 & $5 / 85$ \\
\hline & 1999 & 1361141 & 207487 & 197378 & 10108 & $4 / 87$ \\
\hline & 2000 & 1387138 & 232609 & 223055 & 9555 & $4 / 11$ \\
\hline & 2001 & 1413135 & 257731 & 248731 & 9001 & $3 / 49$ \\
\hline & 2002 & 1439132 & 282854 & 274407 & 8447 & $2 / 99$ \\
\hline & 2003 & 1465128 & 307976 & 300083 & 7893 & $2 / 56$ \\
\hline & 2004 & 1491125 & 333098 & 325759 & 7339 & $2 / 20$ \\
\hline & 2005 & 1505709 & 354257 & 346452 & 7805 & $2 / 20$ \\
\hline & 2006 & 1520292 & 375417 & 367145 & 8271 & $2 / 20$ \\
\hline
\end{tabular}

Source: Estimations of Macroeconomic Bureau of the Management and Planning Organization of Iran 
As it is displayed in Figure 2, unemployment rate in the province permanently continued downward trend between 1997 and 2006.

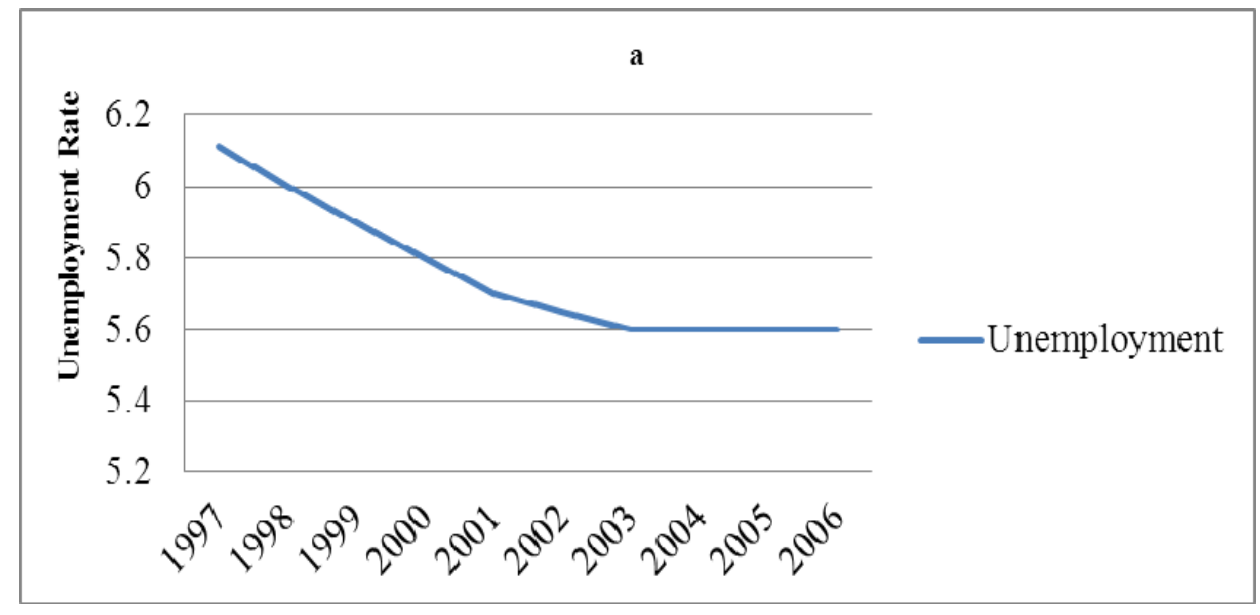

Figure2. The province's unemployment rate process from 1997 to 2006

\subsection{Methodology}

In the present paper, the statistics on the number of issued licenses for new businesses formation is regarded as a criterion for entrepreneurship and unemployment rate of the province, and the relationship between these two variables during the period from 1997 to 2006 is studied by using econometric vector auto-regression model (VAR). In auto-regression vectors, each variable is considered as a function of its own and other variables' lags. A simple form of a VAR model with two variables, in a bivariate state, is shown below:

$$
\begin{aligned}
& y_{t}=b_{10}-b_{12} z_{t}+\gamma_{11} y_{t-1}+\gamma_{12} z_{t-1}+\varepsilon_{y_{t}} \\
& z_{t}=b_{20}-b_{21} y_{t}+\gamma_{21} y_{t-1}+\gamma_{22} z_{t-1}+\varepsilon_{z_{t}}
\end{aligned}
$$

$\varepsilon_{y_{t}}$ and $\varepsilon_{z_{t}}$ have desirable features or, terminologically, "white noise". Since, a correlation exists between

$z_{t}$ and $\varepsilon_{y_{t}}$, as well as and $\varepsilon_{z_{t}}$, the above equations cannot be directly solved, because, applying estimation methods of econometric equations requires the assumption that there is not any intrusion in relationship between descriptive variables and the components. Therefore, by putting $\mathrm{z} 1$, from Relationship 2, in Relationship 1, and by putting y1, from Relationship 1, in Relationship 2, the equations below can be obtained:

$$
y_{t}=\alpha_{10}+\alpha_{11} y_{t-1}+\alpha_{12} z_{t-1}+e_{1 t}
$$

In which: 


$$
\begin{aligned}
& e_{1 t}=\left(\varepsilon_{y_{t}}-b_{12} \varepsilon_{z_{t}}\right) / 1-b_{12} b_{21} \\
& e_{2 t}=\left(\varepsilon_{z_{t}}-b_{21} \varepsilon_{y_{t}}\right) / 1-b_{12} b_{21}
\end{aligned}
$$

Since, $\varepsilon_{y_{t}}$ and $\varepsilon_{\mathrm{z} 1}$ have the desirable features, it can be concluded that parts $e_{1 t}$ and $e_{2 t}$ also have similar behaviors. It is noteworthy that, in the relationships above, just the first lag/pause of the variables has been mentioned, and the number of optimal lags should be determined by employing appropriate tests.

In the current study, two simultaneous equations in the form of vector auto-regression model (VAR) have been used for exploring the effects of unemployment and entrepreneurship on each other:

$$
\begin{aligned}
& U_{t}=\alpha+\sum_{i=1}^{p} \gamma_{i} U_{t-i}+\sum_{j=1}^{p} \beta_{j} E_{t-j}+\sum_{t=1}^{T} \delta_{t} D_{t}+\omega_{1 t} \\
& E_{t}=\theta+\sum_{i=1}^{p} \lambda_{i} U_{t-i}+\sum_{j=1}^{p} \mu_{j} E_{t-j}+\sum_{t=1}^{T} v_{t} D_{t}+\omega_{2 t}
\end{aligned}
$$

In the equations:

$U_{t}=$ The province's unemployment rate

$E_{t}=$ The number of licenses issued each year to create industries and businesses in the province (as a criterion for entrepreneurship)

$D_{t}=$ Dummy Variable

$\mathrm{P}=$ Representative of the number of lags

And $\omega_{1 t}$ and $\omega_{2 t}=$ wastes

In accordance with our expectations and the mentioned theories, the sign $\beta$, standing for the effect of entrepreneurship on unemployment, should be negative, and the $\lambda$, standing for the effect of unemployment rate on entrepreneurship, should be positive.

With regard to the process of industrial licenses' number, and respecting Figure 1, it is recognized that this variable was in its maximum in 2002, consequently, 2002 has been entered into the model as the dummy variable.

\section{Estimation of the model, and analysis of the findings}

In this section, estimation of the model and its results, and analysis of the findings are presented. In the process of estimating Relationships 5 and 6, primarily, VAR order is determined, subsequently, the 
model is estimated. Moreover, the number of optimal lags is determined considering Schawrts Bayesian Criterion (SBC).

Equation 5 Estimate: $\mathrm{U}=1.17+0.798 \mathrm{U}(-1)-0.000128 \mathrm{E}(-1)-0.00486 \mathrm{DUM} 81$

T-statistics: (6.54) (28.07)

Probability: (0.001) (0.000)

$$
R^{2}=0.99
$$

By estimating the above equation, as well as, considering the unemployment rate of the province as a dependent variable, we observe that, entrepreneurship has an inverse relationship with unemployment rate, i.e., a rise in the number of new businesses leads to a fall in unemployment rate. This variable is statistically significant.

Equation 6 estimate: $\mathrm{E}=211.23+10.79 \mathrm{U}(-1)+0.439 \mathrm{E}(-1)+132.34 \mathrm{DUM} 81$

T-statistics: $\quad(0.153) \quad(0.049) \quad(1.208)$

Probability: (0.884) (0.961) (0.281) $\quad R^{2}=0.54$

Regarding the above estimate, and considering entrepreneur as a dependent variable, we observe that the obtained relationship between unemployment rate and entrepreneurship is not statistically significant, i.e., an increase in unemployment rate in the province does not lead to a rise in entrepreneurship, and this relationship, named "refugee effect" does not exist in the province.

Based on the estimates of the two equations above, it can be claimed that there is a negative relationship between entrepreneurship and unemployment rate, i.e., when entrepreneurship boosts, unemployment rate in the province declines.

To sum up, the obtained results indicate that, in the industry of Azarbayjan-e-Shargi province, the entrepreneurial effect exists on the contrary, the refugee effect does not exist.

The majority of studies conducted in this field in developed countries are indicative of a two-way relationship between unemployment and entrepreneurship. Respecting the effect of unemployment on entrepreneurship, some studies reveal that unemployment positively affects entrepreneurship (e.g., Evans \& Leighton, 1990). Some researches, however, find that unemployment negatively influences entrepreneurship (e.g., Audretsch \& Fritsch, 1994; Garofolu, 1994). Accordingly, the results of the performed empirical researches are conflicting concerning the relationship between unemployment rate and entrepreneurship.

Additionally, Carree (2001) reaches the conclusion that there is no statistically significant relationship between unemployment and entrepreneurship. As a consequence, it can be stated that, the results of the current study, suggesting that, in Azarbayjan-e-Shargi, unemployment rate exerts no effect on entrepreneurship quantity, are in accord with those of Carree's (2001) study.

With regard to the effect of entrepreneurship on unemployment rate, the present research results are in agreement with those of Audretsch \& Thurik (2000), indicating that, as entrepreneurship boosts, i.e., the number of new businesses, unemployment rate declines.

To sum up, this paper reveals that the promotion of entrepreneurship in industrial sector of Azarbayjan-e-Shargi provinc causes unemployment rate to soar (entrepreneurial effect), on the contrary, a 
rise or a fall in unemployment does not bring about any effect on entrepreneurship in the province (lack of refugee effect).

As mentioned before, in high unemployment conditions, the entrepreneurial opportunity cost goes down for many people, therefore, it is possible that, a large number of unemployed people are driven into self-employment and entrepreneurship; the reasons of not observing such an effect in the province, which is known as refugee effect, are:

1. Lower level of literacy and educations associated with entrepreneurship in the country and the province compared to entrepreneurial literacy in developed countries.

2. Inadequate attempt to develop entrepreneurial culture in the country and the province.

3. Inefficient entrepreneurial culture for lower level of entrepreneurship.

4. An unfair competition with government-owned businesses (because of state subsidies and uncompetable products of large government-owned industries).

5. High risk of entrepreneurship and investment in the industry for reasons such as: a) instability of rules and regulations, b) cumbersome bureaucracy (long time needed for winning business licenses), c) inefficient labour rules (problems originating from employment), d) weak government support for new firms, and e) lack of an efficient system for providing entrepreneurs with financial resources.

\section{Conclusion}

Today, entrepreneurship, as a generator of employment and a stimulus to economic growth, takes on a growing importance in modern economies. As the government's public policies have developed a tendency towards entrepreneurship, in order to create employment, reduce unemployment rate, and promote economic growth, policy makers, seeking appropriate guidance, resort to theoretical concepts and academic research results to make major decisions. Nonetheless, there are numerous unanswered questions and opinions about the relationship between entrepreneurship and unemployment. A number of economists believe in the positive effect of high unemployment rate on entrepreneurship. This group, referring to the results of their own applied researches, argue that unemployed people do not benefit from the advantages of compensation of (the service of) employees. As a result, in high unemployment and unfavorable labor market conditions, entrepreneurial opportunity cost reduces considerably, hence, more people are convinced to engage in self-employment and creating new businesses. Based on this reasoning, they claim that a rise in unemployment brings about entrepreneurship development. On the other hand, another group of researchers report results which are different from and sometimes conflicting with those reported by the first group. This group identify entrepreneurial endeavors as employment generators and assume an inverse relationship between the variables in question. Arguing that entrepreneurship naturally accompanies creating new business, and every new firm, at least, provides its founder with employment, they justify the inverse relationship between the variables and conclude that entrepreneurship promotion would be accompanied with unemployment rate fall.

Results obtained from the majority of the studies undertaken in recent years indicate that both abovementioned relations exist in most of developed countries, that is, a rise in unemployment rate in these countries leads to the development of self-employment and entrepreneurship (refugee effect). Moreover, the promotion of entrepreneurship and self-employment, itself, brings about a fall in unemployment rate after a few-year interval. In addition to showing refugee effect, the findings of studies are indicative of the negative effect of entrepreneurship raise on unemployment rate (entrepreneurial effect). However, 
according to these findings, entrepreneurial effect is stronger than refugee effect, and the sum of the two effects will finally exert an opposite effect on unemployment rate.

Nevertheless, more uncertainties surrounding the relationship between entrepreneurship and unemployment, with regard to business cycles, occur. A number of academic researches reveal the positive effect of economic recession, as a stimulus to unemployed workforce, on becoming selfemployed and entrepreneur. Whereas, there are ample logical reasons to state that economic growth would have a positive impact on creating more opportunities resulting in a rise in entrepreneurial activities.

New and small firms are known as the pivot of entrepreneurship, and among a range of criteria for quantitative measurement, entrepreneurship is the most commonly used one by the researchers. The current study, in which this criterion is adopted, making attempt to clarify and simplify this complicated relationship, reveals the quality of entrepreneurship's relationship with unemployment rate and its substantial role (the number of new businesses in the industrial sector of Azarbayjan-e-Shargi province) in reducing the rate of unemployment. The results obtained from the present research indicate that the former relationship between the two variables in question in the industrial sector of the province is not statistically significant. That is, hyper unemployment of the province, in spite of the opportunity cost reduction, self-employment, does not have any effect on boosting self-employment and entrepreneurship. Accordingly, the existence of refugee effect in the province in question is not confirmed, which may be related to the low human capital of the unemployed, bureaucracy and high cost of establishing a new business in the province, national culture developed as a result of dependence on oil revenues, a large number of potential competitors state rent, etc., and does not encourage unemployed people to engage in self-employment and start up new firms. By contrast, the finding of this study confirms the existence of entrepreneurial effect in the province, which means that an escalation in self-employment and entrepreneurship rate in manufacturing sector is effective in reducing unemployment rate in the province. To state precisely, entrepreneurship promotion, i.e., setting up new businesses, as much as 100 units, will bring about $.0128 \%$ decrease in unemployment rate in the province. With respect to the high number of unemployed people in the province, and very low universal share of the manufacturing division compared to the service division, the achieved results, which appear to be of high significance, recommend that policy makers should use entrepreneurship development means for reducing unemployment rate in the province.

Consequently, the finding of the present study suggests that the government's public policies, designed to create jobs and reduce unemployment, can be influenced by more attention to innovative entrepreneurships with high growth. Such policies, by increasing the amount of entrepreneurial activities, can considerably reduce unemployment rate in the future. In other words, entrepreneurs, in addition to themselves, employ more unemployed people, who are not able to found and run a new firm, as a result, they decrease unemployment rate in the province.

\section{References}

Acs, Zoltan J., and David B. Audretsch, 2003, Innovation and Technological Change, in: Z.J. Acs and D.B. Audretsch (eds.), Handbook of Entrepreneurship Research, Boston/Dordrecht: Kluwer Academic Publishers, 55-79.

Acs, Zoltan J., Pia Arenius, Michael Hay and Maria Minniti, 2005, Global Entrepreneurship Monitor, 2004 Executive Report, London, UK: London Business School and Wellesley, MA: Babson College.

Audretsch, David B., 1995, Innovation and Industry Evolution, Cambridge, MA: MIT Press.

Audretsch, David B., Martin A. Carree, Adriaan J. van Stel and A. Roy Thurik, 2002, Impeded Industrial Restructuring: The Growth Penalty, Kyklos 55, 81-97. 
Audretsch, David B. and Michael Fritsch, 1994, The Geography of Firm Births in Germany, Regional Studies, 28 (4), 359-365.

Audretsch, David B., Isabel Grilo and A. Roy Thurik, 2007, Handbook of Research in Entrepreneurship Policy, Cheltenham, UK and Northampton, MA, US: Edward Elgar Publishing Ltd.

Audretsch, David B. and Max Keilbach, 2004, Entrepreneurship Capital and Economic Performance, Regional Studies 38, 949959.

Audretsch, David B. and A. Roy Thurik, 2000, Capitalism and Democracy in the 21st Century: from the Managed to the Entrepreneurial Economy, Journal of Evolutionary Economics 10, 17-34.

Audretsch, David B. and A. Roy Thurik, 2001, What is New about the New Economy: Sources of Growth in the Managed and Entrepreneurial Economies, Industrial and Corporate Change 10 (1), 267-315.

Audretsch, David B., A. Roy Thurik, Ingrid Verheul and Sander Wennekers, 2002, Entrepreneurship: Determinants and Policy in a European-US Comparison, Boston/Dordrecht: Kluwer Academic Publishers.

Beesley, M.E. and M.T. Hamilton, 1984, Small Firms' Seedbed Role and the Concept of Turbulence, Journal of Industrial Economics 33, 217-231.

Blanchflower, D.G., 2000, Self-employment in OECD countries, Labour Economics 7, 471-505.

Blanchflower, Danny and Bruce Meyer, 1994, A Longitudinal Analysis of Young Entrepreneurs in Australia and the United States, Small Business Economics 6 (1), 1-20.

Carree, Martin, 2002, Does Unemployment Affect the Number of Establishments? A Regional Analysis for U.S. States, Regional Studies 36, 389-398.

Carree, Martin, André van Stel, Roy Thurik and Sander Wennekers, 2002, Economic Carree,

Carree, Martin A. and A. Roy Thurik, 2003, The Impact of Entrepreneurship on Economic Growth, in D.B. Audretsch and Z.J. Acs (eds.), Handbook of Entrepreneurship Research, Boston/Dordrecht: Kluwer Academic Publishers, 437-471.

Carree, Martin A. and A. Roy Thurik, 2007, The Lag Structure of the Impact of Business Ownership on Economic Growth in OECD Countries, Small Business Economics, forthcoming.

Caves, R.E., 1998, Industrial Organization and New Findings on the Turnover and Mobility of Firms, Journal of Economic Literature 36, 1947-1982.

Congregado, E., A. Golpe and J.M. Millán, 2005, Determinantes de la Oferta de Empresarios, in: García, J. and J. Pérez (eds.), Cuestiones Clave de la Economía Española, Perspectivas actuales 2004, Ed. Comares, 165-187.

Dunne, Timothy, Mark J. Roberts and Larry Samuelson, 1988, Patterns of Firm Entry and Exit in U.S. Manufacturing Industries, RAND Journal of Economics 19, 495-515.

Dunne, Timothy, Mark J. Roberts and Larry Samuelson, 1989, The Growth and Failure of US Manufacturing Plants, Quarterly Journal of Economics 104, 671-698.

Evans, David S., 1987a, The Relationship between Firm Growth, Size and Age: Estimates for 100 Manufacturing Industries, Journal of Industrial Economics 35 (2), 567-581.

Evans, David S., 1987b, Tests of Alternative Theories of Firm Growth, Journal of Political Economy 95 (4), 657-674.

Evans, David S. and Boyan Jovanovic, 1989, Estimates of a Model of Entrepreneurial Choice under Liquidity Constraints, Journal of Political Economy 97 (3), 657-674.

Evans, David S., and Linda S. Leighton, 1989, The Determinants of Changes in U.S. Self-Employment, 1968-1987, Small Business Economics 1 (2), 111-120.

Evans, David S. and Linda Leighton, 1990, Small Business Formation by Unemployed and Employed Workers, Small Business Economics 2 (4), 319-330.

Fritsch, Michael, and Pamela Mueller, 2004, The Effects of New Business Formation on Regional Development over Time, Regional Studies 38, 961-975.

Garofoli, Gioacchino, 1994, New Firm Formation and Regional Development: The Italian Case, Regional Studies 28 (4), 381 394.

Geroski, Paul A., 1989, Entry, Innovation, and Productivity Growth, Review of Economics and Statistics 71, 572-578.

Geroski, Paul A., 1995, What Do We Know About Entry? International Journal of Industrial Organization, 13, 421- 440. 
Granger, C.W.J., 1969, Investigating Causal Relations by Econometric Models and Cross-Spectral Methods, Econometrica 37, 424-438.

Grilo, Isabel and Jésus-Maria Irigoyen, 2006, Entrepreneurship in the EU: to Wish and Not to Be, Small Business Economics 26 (4), 305-318.

Grilo, Isabel and Roy Thurik, 2005, Entrepreneurial Engagement Levels in the European Union, Interna-tional Journal of Entrepreneurship Education 3 (2), 143-168.

Hall, Bronwyn H., 1987, The Relationship between Firm Size and Firm Growth in the U.S. Manufacturing Sector, Journal of Industrial Economics 35, June, 583-605.

Hamilton, Robert T., 1989, Unemployment and Business Formation Rates: Reconciling Time Series and Cross Section Evidence, Environment and Planning 21, 249-255.

Hart, P.E. and N. Oulton, 1999, Gibrat, Galton and Job Generation, International Journal of the Economics of Business 6, 149164.

Hayek, F.A., 1945, The Use of Knowledge in Society, American Economic Review 35, 519-530.

Highfield, R. and Robert Smiley, 1987, New Business Starts and Economic Activity: An Empirical Investigation, International Journal of Industrial Organization 5, 51-66.

Hurst, E. and A. Lusardi, 2004, Liquidity Constraints, Household Wealth and Entrepreneurship, Journal of Political Economy 112 (2), 319-347.

Johansson, E., 2000, Self-Employment and Liquidity Constraints: Evidence from Finland, Scandinavian Journal of Economics $102,123-134$.

Klomp, Luuk, Enrico Santarelli and Roy Thurik, 2006, Gibrat's Law: an Overview of the Empirical Literature, in E. Santarelli (ed.), Entrepreneurship, Growth, and Innovation: the Dynamics of Firms and Industries: International Studies in Entrepreneurship, Berlin: Springer Science, 41-73.

Knight, Frank H., 1921, Risk, Uncertainty and Profit, New York: Houghton Mifflin.

Lin, Zhengxi, Marilyn E. Manser and Garnett Picot, 1998, The Role of Self-Employment in Job Creation In Canada and the U.S., OECD-CERF-CILN International Conference on Self-Employment, Burling-ton, Ontario, Canada.

Mueller, Stephen L. And Anisya S. Thomas, 2000, Culture and Entrepreneurial Potential: A Nine Country Study of Locus of Control and Innovativeness, Journal of Business Venturing 16, 51-75.

Nickell, S.J., 1996, Competition and Corporate Performance, Journal of Political Economy 104, 724-746.

Nickell, S., P. Nicolitsas and N. Dryden, 1997, What Makes Firms Perform Well? European Economic Review 41, 783-796.

Oxenfeldt, A., 1943, New Firms and Free Enterprise, Washington, D.C.: American Council on Public Affairs.

Parker, Simon C., 2004, The Economics of Self-Employment and Entrepreneurship, Cambridge, UK: Cambridge University Press.

Pfeiffer, F. and Reize, F., 2000, Business Start-ups by the Unemployed - an Econometric Analysis Based on Firm Data, Labour Economics 7 (5), 629-663.

Reynolds, P., B. Miller and W.R. Maki, 1995, Explaining Regional Variation in Business Births and Deaths: U.S. 1976-1988, Small Business Economics 7 (5), 389-707. Jena Economic Research Papers 2007-089 20

Reynolds, Paul, David J. Storey and Paul Westhead, 1994, Cross-National Comparisons of the Variation in New Firm Formation Rates, Regional Studies 28 (4), 443-456.

Schumpeter, Joseph A., 1934, The Theory of Economic Development, Cambridge, MA: Harvard University Press.

Sims, Christopher A., 1980, Macroeconomics and Reality, Econometrica 48, 1-48.

Stel, André van, 2005, COMPENDIA: Harmonizing Business Ownership Data Across Countries and Over Time, International Entrepreneurship and Management Journal 1 (1), 105-123.

Stel, André van, Martin Carree and Roy Thurik, 2005, The Effect of Entrepreneurial Activity on National Economic Growth, Small Business Economics 24 (3), 311-321.

Stel, Adriaan J. van, and David J. Storey, 2004, The Link between Firm Births and Job Creation: Is there a Upas Tree Effect? Regional Studies 38 (8), 893-909. 
Kheiravar and Qazvini., International Journal of Organizational Leadership, Vol. 1 No. 2 (2012)

Stel, André van, and Kashifa Suddle, 2007, The Impact of New Firm Formation on Regional Development in the Netherlands, Small Business Economics, forthcoming.

Storey, David J., 1991, The Birth of New Firms - Does Unemployment Matter? A Review of the Evi-dence, Small Business Economics 3 (3), 167-178.

Sutton, John, 1997, Gibrat's Legacy, Journal of Economic Literature.,35, 40-59.

Thurik, Roy, 1999, The Dutch Polder Model: Shifting from the Managed Economy to the Entrepreneurial Economy, Annual Meeting of the American Economic Association New York, NY, January 3-5, 1999. 